\title{
Leadership for Engineers: A Course for Developing Professional and Busi- ness Skills for Engineers
}

\section{Dr. Decker B. Hains, Western Michigan University}

Dr. Decker B. Hains is a Master Faculty Specialist in the Department of Civil and Construction Engineering at Western Michigan University. He is a retired US Army Officer serving 22 years on active duty with the US Army Corps of Engineers and taught at the United States Military Academy at West Point (USMA). He earned a Bachelor of Science degree in Civil Engineering from USMA in 1994, Master of Science degrees from the University of Alaska Anchorage in Arctic Engineering in 1998 and Missouri University Science \& Technology in Civil Engineering in 1999, and a PhD in Civil Engineering from Lehigh University in 2004. He is a registered Professional Engineer in Michigan.

Dr. Bret J. Wagner, Western Michigan University 


\title{
Leadership for Engineers: A Course for Developing Professional and Business Skills for Engineers
}

\begin{abstract}
Employers consistently cite leadership and professional skills as some of the most desirable abilities for engineering graduates. Unfortunately, it is rare to have these skills explicitly taught to engineers in the classroom, so graduates are left to develop these skills on their own. Moreover, knowledge of fundamental business functions is increasingly important for civil engineers.
\end{abstract}

To address these needs, the authors developed a course, Leadership for Engineers, and used an interactive and highly engaging business simulation, ScrimmageSim ${ }^{\mathrm{TM}}$, to create an active learning environment where students are placed in leadership positions and are required to develop basic business operating plans; execute these plans in the simulation; and reflect on their team's successes, failures and missed opportunities. The authors piloted the course during summer 2017 with students majoring in both engineering and business.

This paper addresses the development, execution and assessment of this course. The development of the course included sequencing specific seminars on leadership and business topics with six business simulation scenarios. For each of the business simulation scenarios, the teams developed business plans, executed, and an after-action review to capture lessons learned. During the execution of the simulations, three-member student teams, with one member designated as the leader, operated a simulated brewery, making decisions on what to produce, what prices to set, and other critical decisions depending on the scenario. The ScrimmageSim ${ }^{\mathrm{TM}}$ software provided real-time reports on the status of the simulated company so the impacts of their business decisions were readily apparent. Each successive simulation featured additional options requiring more complicated business decisions.

All team and students received feedback on their performance for each of the simulations. Teams presented their business plans and briefed on the lessons learned. The authors conducted an extensive end-of-course survey to assess the quality of the course and the contribution of the course to student learning about leadership, business and professional skills. The paper will detail the development and execution of the course as well as an assessment of how well the course met the stated objectives.

\section{Introduction}

As shown in the table below depicting the results of the 2017 National Association of Colleges and Employers survey on attributes employers are seeking, employers consistently cite leadership and professional skills as some of the most desirable abilities for graduates (see Table 1). Yet these skills are rarely part of an engineering curriculum that is typically focused on technical topics. Anecdotally, many graduates starting out in 
engineering firms report that they need knowledge on fundamental business functions to better understand the role of engineering in helping a business organization be profitable.

Table 1. Attributes Employers Seek on a Candidate's Resume [1]

\begin{tabular}{|l|l|c|}
\hline & \multicolumn{1}{|c|}{ ATTRIBUTE } & $\begin{array}{c}\text { PERCENTAGE OF } \\
\text { RESPONDENTS }\end{array}$ \\
\hline 1 & Ability to work in a team & $78.0 \%$ \\
\hline 2 & Problem-solving skills & $77.3 \%$ \\
\hline 3 & Communication skills (written) & $75.0 \%$ \\
\hline 4 & Strong work ethic & $72.0 \%$ \\
\hline 5 & Communication skills (verbal) & $70.5 \%$ \\
\hline 6 & Leadership & $68.9 \%$ \\
\hline 7 & Initiative & $65.9 \%$ \\
\hline 8 & Analytical/quantitative skills & $64.4 \%$ \\
\hline 9 & Flexibility/adaptability & $63.6 \%$ \\
\hline 10 & Detail-oriented & $62.1 \%$ \\
\hline 11 & Interpersonal skills & $58.3 \%$ \\
\hline 12 & Technical skills & $56.8 \%$ \\
\hline 13 & Computer skills & $49.2 \%$ \\
\hline 14 & Organizational ability & $47.7 \%$ \\
\hline 15 & Strategic planning skills & $37.9 \%$ \\
\hline 16 & Friendly/outgoing personality & $25.8 \%$ \\
\hline 17 & Tactfulness & $25.8 \%$ \\
\hline 18 & Creativity & $21.2 \%$ \\
\hline 19 & Entrepreneurial skills/risk-taker & $19.7 \%$ \\
\hline 20 & Fluency in a foreign language & $4.5 \%$ \\
\hline
\end{tabular}

To address these needs, the authors developed a course, Leadership for Engineers, and used an interactive and highly engaging business simulation, ScrimmageSim ${ }^{\mathrm{TM}}$, to create an active learning environment where students were placed in leadership positions and were required to develop basic business operating plans; execute plans; and reflect on their successes, failures and missed opportunities.

\section{Course Design}

To begin the course development process, the authors developed a comprehensive but concise course description and succinct course learning objectives. The course description is:

"Leadership is in great demand in the business world. Leaders are needed in all types of organizations and at all levels within organizations. This seminar course is designed to provide students with opportunities to develop their leadership and teamwork skills as well as their business acumen through stimulating experiences in 
leadership positions. The goal of the course is to provide students multiple leadership experiences in a business environment through the use of an interactive simulation."

The course objectives are as follows:

1. Explain key concepts in leadership and formulate a personal definition of leadership.

2. Develop a plan for personal leadership development and demonstrate the ability for self-directed learning.

3. Explain the key factors which drive the successful operation of a business and apply these concepts to successfully operate a simulated business.

4. Plan, compose, and deliver effective verbal, written, and graphical communications related to business operations.

5. Assess the leadership abilities of others through the application of effective interpersonal skills.

6. Demonstrate effective leadership in the planning and the execution of operational plans in a dynamic environment.

To achieve these objectives, the authors identified and sequenced four major learning components compromised of several learning activities. The four major learning components in the course were short, instructor-led seminars, in-class discussions on reading assignments and videos, personal leadership assessments, and activities related to the business simulation.

The table below shows the course schedule based on a 14-week semester or 7-week (2 classes per week) summer session meeting 2.5 hours per week/class.

Table 2. Leadership for Engineers Course Outline

\begin{tabular}{|l|l|}
\hline $\begin{array}{c}\text { Week or } \\
\text { Class }\end{array}$ & \multicolumn{1}{c|}{ Topic } \\
\hline 1 & $\begin{array}{l}\text { Course Introduction } \\
\text { Introduction to Leadership Seminar } \\
\text { Decision-Making Seminar } \\
\text { Simulation 1 Planning }\end{array}$ \\
\hline 2 & $\begin{array}{l}\text { Simulation 1 Execution } \\
\text { Simulation 1 Group After Action Review (AAR) } \\
\text { Myers-Briggs Type Indicator Assessment } \\
\text { Leadership Traits, Attributes \& Actions Seminar }\end{array}$ \\
\hline 3 & $\begin{array}{l}\text { Leadership Traits, Attributes \& Actions Video Discussion } \\
\text { Simulation 2 Planning and Team Briefs } \\
\text { Simulation 2 Execution }\end{array}$ \\
\hline
\end{tabular}




\begin{tabular}{|l|l|}
\hline 4 & $\begin{array}{l}\text { Simulation 2 Execution } \\
\text { After Action Review Seminar } \\
\text { Simulation 2 Team AAR Preparation }\end{array}$ \\
\hline 5 & $\begin{array}{l}\text { Leadership Video Discussion } \\
\text { Leadership Theories Seminar } \\
\text { Simulation 2 Team AAR Briefs } \\
\text { Presentation Design Seminar }\end{array}$ \\
\hline 6 & $\begin{array}{l}\text { Simulation 3 Team Planning \& Briefs } \\
\text { Interpersonal Communications \& Feedback Techniques Seminar }\end{array}$ \\
\hline 7 & $\begin{array}{l}\text { Crucial Conversations Video Discussion } \\
\text { Simulation 3 Execution } \\
\text { Simulation 3 Team AAR Preparation }\end{array}$ \\
\hline 9 & $\begin{array}{l}\text { Simulation 3 Team AAR Briefs } \\
\text { Presentation Delivery Seminar } \\
\text { Simulation 4 Team Planning }\end{array}$ \\
\hline 10 & $\begin{array}{l}\text { Simulation 4 Team Briefs } \\
\text { Simulation 4 Execution }\end{array}$ \\
\hline 11 & $\begin{array}{l}\text { Emotional Intelligence Video Discussion } \\
\text { Leadership Traits, Attributes \& Actions Reading Discussion } \\
\text { Simulation 4 Team AAR Briefs } \\
\text { Crucial Conversations Seminar } \\
\text { Performance Counseling and Evaluations Seminar }\end{array}$ \\
\hline $\begin{array}{l}\text { Simulation 5 Team Planning and Briefs } \\
\text { Simulation 5 Execution }\end{array}$ \\
\hline 12 & $\begin{array}{l}\text { Simulation 5 Execution } \\
\text { DisCC Assessment } \\
\text { Emotional Intelligence Seminar } \\
\text { Simulation 5 Team AAR Preparation }\end{array}$ \\
\hline $\begin{array}{l}\text { Organizational Culture and Strategic Leadership Reading Discussion } \\
\text { Organizational Culture Seminar } \\
\text { Simulation 5 Team AAR Briefs } \\
\text { Strategic Planning Seminar } \\
\text { Simulation 6 Team Planning }\end{array}$ \\
$\begin{array}{l}\text { Simulation 6 Team Plan Briefs } \\
\text { Simulation 6 Execution } \\
\text { Simulation 6 Group AAR } \\
\text { Course Summary } \\
\text { End of Course AAR }\end{array}$ \\
\hline 13 & \\
\hline 14
\end{tabular}




\section{Instructor-Led Seminars}

The course featured 13 short (45 minutes or less) seminars on various leadership topics sequenced throughout the course to provide leadership tools and concepts for students to apply in the increasingly complicated simulations. These seminars included:

- Introduction to Leadership

- Decision-Making

- Leadership Characteristics \& Attributes

- After Action Reviews

- Leadership Theories

- Presentation Design

- Interpersonal Communications \& Feedback Techniques

- Presentation Delivery

- Crucial Conversations

- Performance Counseling and Evaluations

- Emotional Intelligence

- Organizational Cultural

- Strategic Planning

\section{Instructor-Facilitated Discussions}

To complement the concepts and theories taught in the seminars, the authors facilitated discussions based on assigned readings and videos. Each of these discussions were preceded by a homework assignment which required the students to answer several prompts about the reading or video. These discussions included:

- Leadership traits, attributes and actions based on a documentary about Ernest Shackleton's Antarctic Expedition

- The failure to designate leadership based on the Precise Graphix episode from CNBC's television show, "The Profit"

- Crucial conversations and delivering feedback based on the Eco-Me episode from CNBC's television show, "The Profit"

- Emotional intelligence based on the Mr. Green Tea II episode from CNBC's television show, "The Profit"

- Leadership traits, attributes and actions based on Elbert Hubbard's “A Message to Garcia"

- Organizational culture and strategic leadership based on a selected chapter of the book, American Icon by Bryce G. Hoffman

\section{Personal Leadership Assessments}

The authors feel strongly that personal leadership assessments must be a core component of leadership education and development. To provide this assessment, three distinct leadership assessment tools were included in the course. Because personality plays a large role in effective leadership and is critical to understanding oneself, students completed the 
Myers-Briggs Type Indicator ${ }^{\circledR}$ assessment tool and reflected on their results. More specific to leadership, students also completed the DiSC ${ }^{\circledR}$ Personality Assessment, which more specifically addresses leadership styles and how to build effective relationships.

The dynamic, interactive, and competitive nature of the simulations provides an opportunity for the students to assume a leadership position and work in teams.

To assess the leader's performance, the authors developed a leadership assessment tool, which is shown in Figure 1. The authors used the ROTC Leadership Assessment Report Form 156-4A-R July 09 as a starting point because it is a proven tool for the assessment of developing leaders. Of course, there were aspects of this assessment tool that did not apply in the civilian world, so the authors modified to meet the needs of a professional environment. This tool provided a comprehensive tool to evaluate leadership and provide consistent feedback for students in the course. 


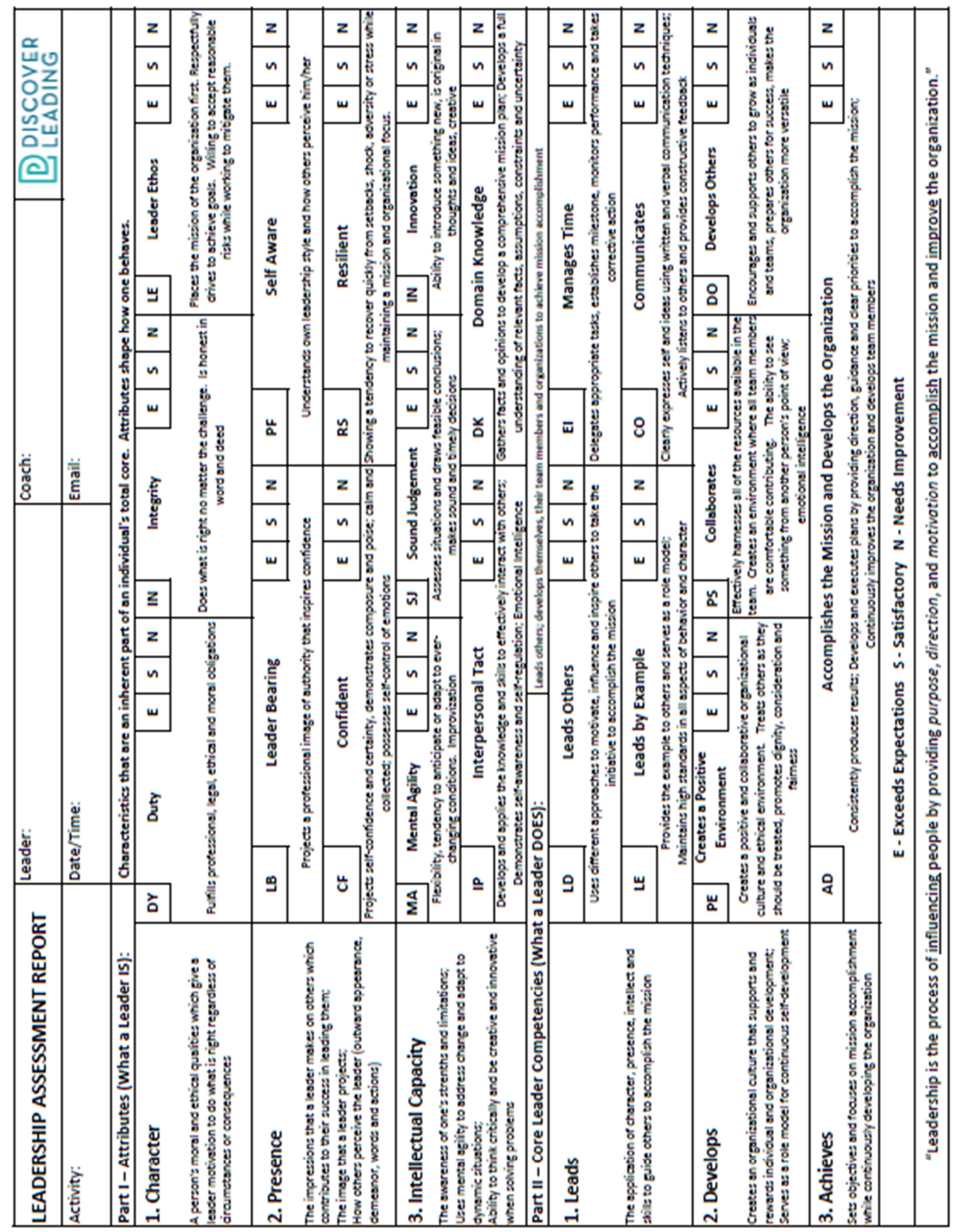

Figure 1. Leadership Assessment Report 


\section{Simulation Learning}

A key feature of the course was the use of a business simulation as the leadership environment. By using a business simulation, students in the course were exposed to business concepts and the challenges in running a business organization. Choosing an appropriate business simulation was a critical decision. Bell and Loon [2] cite the following shortcomings of computer business simulations:

1) The lack of suitability for gaining theoretical knowledge [3]

2) The requirement for other traditional teaching required in combination [4]

3) The risk that an oversimplified or unrealistic simulation may result in some participants "switching off" [5], [6]

4) Team conflict and freeloading of some participants [5], [7]

5) Lack of flexibility [8]

6) Lack of effectiveness in general [9]

These potential shortcomings were important in selecting the business simulation to serve as the leadership experience for the course. The majority of business simulations focus on strategy or marketing and operate at a more theoretical and strategic level. The authors felt that many of these simulations would not be suitable for the leadership experience as the students would not likely have the business background. In addition, many of these simulations require a large number of student decisions and data input for each round, which could lead to issues with student engagement. In addition, these simulations tend to be turn-based, so that the business decisions are entered on one day, then the next day the results are provided to the student on how their business performed after a year of simulated time. To provide the proper leadership environment and suitable business basis, the simulation must function in real time. The ScrimmageSIM ${ }^{\mathrm{TM}}$ Business Simulation was selected for this course for a number of reasons:

1) It is designed as an Enterprise Resource Planning system, so that it operates like actual business software and functions in real time.

2) The simulation has a number of different business scenarios, including a series of six scenarios with the same business context, operating a small brewery, where additional business decisions are added in each scenario.

3) The simulation scenarios allow students to understand the integration of business topics in operations, economics, accounting, marketing and finance, providing a solid foundation for understanding business.

4) Detailed user activity reports allow for identification of "freeloaders."

The authors developed the learning process model shown in figure 2 to provide multiple opportunities or scenarios, namely six for this course, for teams to execute the business and be evaluated both on their performance operating the business and on their leadership and teamwork. For each scenario, the authors provided the teams with a mission document that defined the problem and established objectives for the scenario. In all scenarios, the objective was to maximize net income for the firm. As the course progressed, the scenarios became more complex with added decision-making variables. 


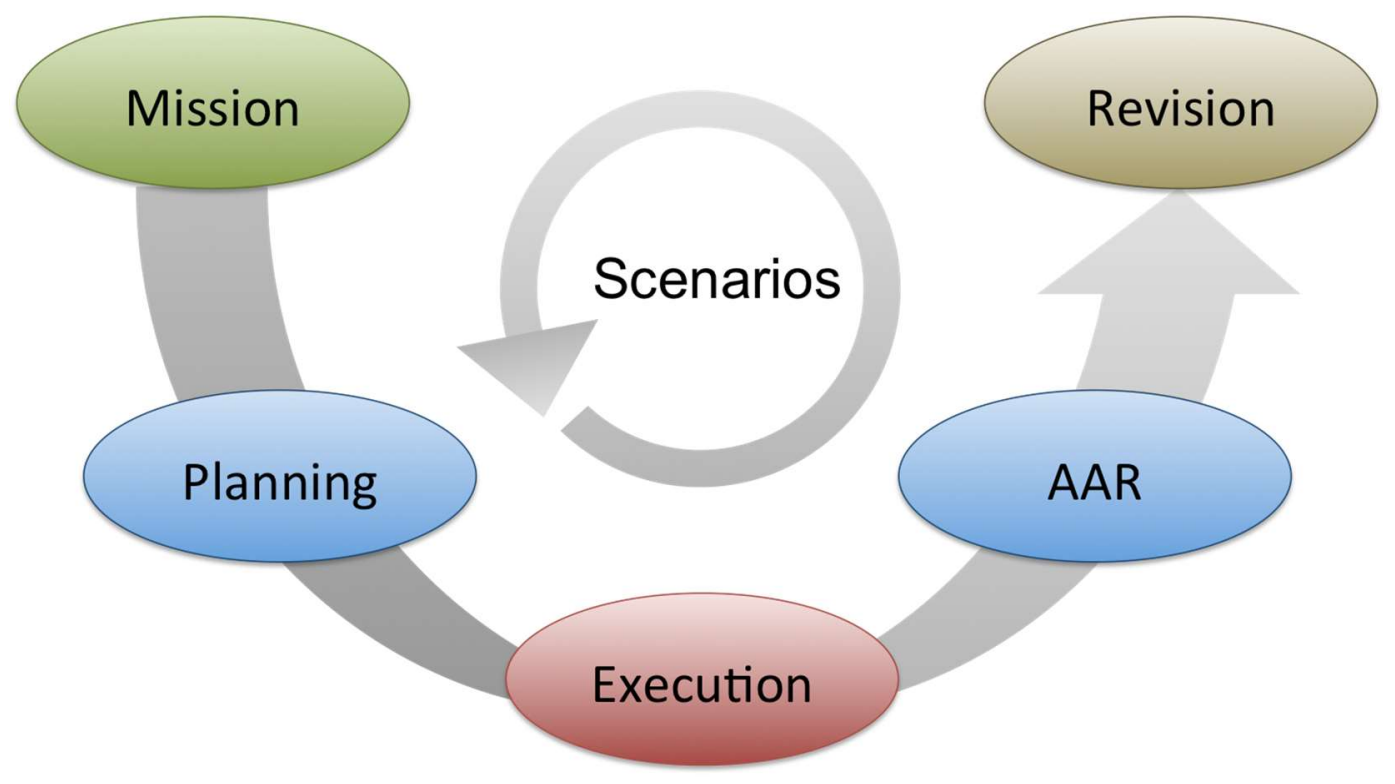

Figure 2. The Simulation Learning Process

With the mission clearly defined, the student teams we required to develop a business plan that included a projection of net income for the company during the simulation, which lasted for one simulated year. The teams were provided with a planning spreadsheet that allowed for the development of an aggregated monthly business plan. One of the leadership challenges was to turn this aggregate plan into real-time decisions during the operation of the simulation.

The spreadsheet model was part of a business plan that students to the instructors prior to the execution of the simulation. Having teams brief their business plan provided an opportunity for the students to refine their presentation skills. Significant emphasis was placed on how to prepare and deliver effective presentations. Using the business plan as a base, students executed the simulation using their plan as a guide to their decision-making but often had to adjust their plans during the simulation due to deliberate randomness in the programming which mimics the real-world business environment.

Soon after completing the simulation, students prepared an After Action Review (AAR) for the scenario and business year that they had just executed. The AAR is loosely based on the US Army process of objectively evaluating an activity and developing plans to improve performance in future activities. The four key components in the AAR process are illustrated in figure 3 and critical factors that increase their effectiveness include:

- Conduct them as soon after the event as possible,

- Including all participants and ensuring they engage in the discussion, and

- Maintaining the purpose of the AAR is for solving problems and not assessing blame 


\begin{tabular}{|c|c|}
$\begin{array}{c}\text { What was } \\
\text { supposed to } \\
\text { happen? }\end{array}$ & $\begin{array}{c}\text { What actually } \\
\text { happened? }\end{array}$ \\
\hline $\begin{array}{c}\text { Why was } \\
\text { there a } \\
\text { difference? }\end{array}$ & $\begin{array}{c}\text { What can we } \\
\text { learn from } \\
\text { this? }\end{array}$ \\
\hline
\end{tabular}

\section{Agreed Facts

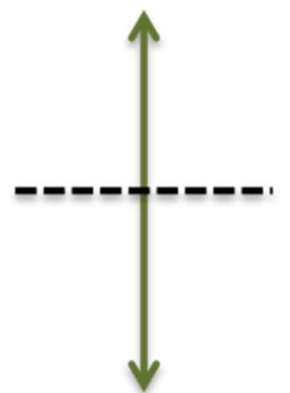 \\ Shared Opinions}

Figure 3. Components of the After Action Review (AAR) Process

The AAR is something that the author's feel is frequently lacking both in higher education and business practice. Like the business plan, student teams were required to present their AAR and were critiqued on their presentation skills. Finally, student teams were expected to use the AAR process to make revisions in their business planning, as the next scenario would contain all of the features of the previous scenario plus new considerations. Table 3 summarizes the key business decisions of each scenario.

Table 3. Scenario Summary

\begin{tabular}{|c|l|}
\hline Scenario & Business Decisions \\
\hline 1 & Production \\
\hline 2 & Production, pricing \\
\hline 3 & Production, pricing, marketing \\
\hline 4 & Production, pricing, marketing cash management, \\
\hline 5 & $\begin{array}{l}\text { Production, pricing, marketing, cash management, capacity } \\
\text { expansion }\end{array}$ \\
\hline 6 & $\begin{array}{l}\text { Production, pricing, marketing, cash management, capacity } \\
\text { expansion, new product introduction }\end{array}$ \\
\hline
\end{tabular}

As noted above, in the simulation process, including planning, executing and reflecting on performance, students progressively learn about several key business functions. For scenario 1, students are tasked to make two simple decisions, what products to produce and when to produce 
them. They realize that they cannot meet the demand for their products and therefore, have to prioritize production orders largely based on profit margin and sales.

For scenario 2, students have the ability to adjust the pricing of their products and learn about the price elasticity of demand. They incorporate the elastic into their planning and execution to address and control capacity issues. During simulation 3, students face decisions on marketing their products and are introduced to the nuances of marketing products and trying to predict marketing success. They use a cost-benefit analysis to decide on the magnitude and timing of marketing campaigns.

In scenario 4, students are introduced to the principles and concepts of managing cash in a business. In this scenario, they have the ability to use profits to pay down loans, thus saving on interest expenses. In Scenario 5, the simulation builds on the cash management function as students have the option to borrow money to invest in additional capacity and must make this costbenefit decision.

For the capstone scenario, which includes all of the features introduced in scenarios 1 through 5, students have the option to introduce a new product to expand their product mix and generate additional net income. With all of these features, student experience the complexity of business operations in a simulated environment and learn about the interaction among these business functions.

Finally, the instructors also have the ability to introduce real-world challenges, such as maintenance problems that unexpectedly reduce capacity and competitor price adjustments, which force the teams to react.

\section{Course Assessment}

During the first offering of the course in summer 2017, 18 students took the course and it was evenly divided between nine engineering students and nine business students. This provided a unique opportunity to integrate engineering and business with students familiar with each but not necessarily the other.

\section{End of Course Survey}

One of the most valuable sources of assessment data comes in the form of feedback provided by the students during the end of course survey. This anonymous feedback consists of a number of questions for which the student provides an answer on a 5-point Likert scale as well as a few openended questions for the students to provide written comments on the course. The authors acquired other assessment data throughout the course of the semester, such as minute papers or muddiest point papers to gage student attitudes and perceptions during the course. However, these are more useful for in-course corrections while the end of course numerically-based feedback is extremely useful for assessing the overall course and for guiding improvements to the course.

The end of course survey featured four major sections: questions about the course, questions directly asking about the course objectives, questions about instructor effectiveness, and open- 
ended questions. Since the focus of this paper is about the course, questions about instructor effectiveness are not addressed here.

Overall, the course was a resounding success as evidenced by the data shown in tables 4 and 5 below. On the 5-point Likert scale a rating of 5 meant that the students "Strongly Agree" while a 1 meant that they "Strongly Disagree".

Table 4. Results of the Course Questions

\begin{tabular}{|l|c|}
\hline \multicolumn{1}{|c|}{ Course Questions } & $\begin{array}{c}\text { Average } \\
\text { Rating }\end{array}$ \\
\hline In this course, my critical thinking ability increased. & 4.73 \\
\hline $\begin{array}{l}\text { Working with fellow students in my group contributed to my learning in this } \\
\text { course. }\end{array}$ & 4.73 \\
\hline $\begin{array}{l}\text { My motivation to continue learning about the course topics has increased } \\
\text { because of this course. }\end{array}$ & 4.80 \\
\hline $\begin{array}{l}\text { My motivation to assume leadership roles in business and/or other } \\
\text { organizations increased because of this course. }\end{array}$ & 4.80 \\
\hline $\begin{array}{l}\text { My ability to produce and deliver professional presentations increased } \\
\text { because of this course. }\end{array}$ & 4.93 \\
\hline The simulation exercises helped me to be more engaged in the course & 4.73 \\
\hline
\end{tabular}

Clearly students felt their motivation for learning more about leadership and business operations increased and they appear to me more motivated to pursue leadership opportunities. Students appreciated the numerous opportunities to develop plans and after action reviews and receive feedback when presenting them. Finally, the survey results also strongly support the use of the simulation exercises to maintain student engagement throughout the course.

Table 5. Results of the Course Learning Objectives Questions

\begin{tabular}{|l|c|}
\hline \multicolumn{1}{|c|}{ Course Learning Objectives Questions } & $\begin{array}{c}\text { Average } \\
\text { Rating }\end{array}$ \\
\hline $\begin{array}{l}\text { Explain key concepts in leadership and formulate a personal definition of } \\
\text { leadership. }\end{array}$ & 4.80 \\
\hline $\begin{array}{l}\text { Develop a plan for personal leadership development and demonstrate the } \\
\text { ability for self-directed learning. }\end{array}$ & 4.80 \\
\hline $\begin{array}{l}\text { Explain the key factors which drive the successful operation of a business } \\
\text { and apply these concepts to successfully operate a simulated business }\end{array}$ & 4.53 \\
\hline $\begin{array}{l}\text { Plan, compose, and deliver effective verbal, written, and graphical } \\
\text { communications related to business operations. }\end{array}$ & 4.73 \\
\hline $\begin{array}{l}\text { Assess the leadership abilities of others through the application of effective } \\
\text { interpersonal skills. }\end{array}$ & 4.60 \\
\hline $\begin{array}{l}\text { Demonstrate effective leadership in the planning and execution of } \\
\text { operational plans in a dynamic environment. }\end{array}$ & 4.67 \\
\hline
\end{tabular}


The course learning objective questions results indicate strong student learning in leadership topics and in communication skills. The authors recognize the need to focus on improving the integration of business factors and functions in future course offerings.

\section{Reflection Assignment}

In addition to the end of course survey, the authors sought to measure the effectiveness of the course by asking students two essay questions as a part of their take-home final exam. The questions were as follows:

1. Discuss your definition of leadership and what you consider essential elements of leadership. How have your perspectives on leadership changed throughout this course?

2. Discuss how you plan to use what you learned in this course as an individual in your personal life, in organizations in which you belong and/or work, and as a leader in general. Include some of the key concepts, content, perceptions, and attitudes that you observed and learned. Discuss your plan for self-development in leadership for the next two to five years.

The responses varied; however there were several common themes. Many discussed the critical aspect of influence as it relates to leadership and how they had not consider this aspect much before taking the course. One student remarked, "I am so glad I took this course. It completely changed my perspective on leadership."

Another stated, "I got the opportunity to be a leader. I tried to balance between my traits, abilities, behaviors, sources of power, and many aspects of each situation. I adopted the role of instilling motivation for my team and had the ability to influence them in accomplishing our group objectives. I had the chance to develop skills that will enable me to be immediately successful upon graduation and give me a better chance to be qualified for a new job and stay on the fast track."

The value of after-action reviews were cited by numerous students as well. One commented, "This course has helped me to better evaluate the holistic nature of organizational success." Others mentioned the importance and increased knowledge of emotional intelligence as well as the value of self-assessment, crucial conversations, and feedback. A student remarked, "I know that I have already seen a difference in my workplace actions, and hopefully my leadership ability will continue to develop."

The role and practice of decision making and resource management were also cited as critical elements in the course. One student commented, "The simulations that we performed in class taught me how to work under pressure. When something would go wrong, such as equipment failure, it was important to keep calm and find a quick solution...Turning stressful situations into constructive development is key to effective leadership and can only be performed with help from others." The simulations provided ample opportunities for real-time decision-making with consequences that were soon realized and addressed. This unique aspect of the course lead to definite growth for the students. 
The most comprehensive comment on the course summarized the experience quite well:

"It's important to mention that the course is dynamic and interactive, and was not about throwing information and slide shows. We had many case studies related to leadership that needed our reflection and discussion. Most of these cases were true stories which put us in a position to discuss the reasons behind real people's success and failure in leading businesses/groups. Moreover, we had to simulate business-related events, and this simulation required team work with a defined leader, analysis for planning and briefing management, executing the plans, decision making, and review of the actions after each task. This, in turn, put us in real situations, to be leaders, followers, decision makers, analysts, and doers."

\section{Conclusion}

The course will be offered again in summer 2018 and serves as the basis in the development of a leadership workshop targeting both engineering and business professionals. The authors plan to incorporate lessons learned from the first offering and plan to develop more robust pre- and postcourse assessments to better measure the effectiveness of the course and use of the business simulation for developing leadership, teamwork, and increasing business knowledge for civil engineers.

\section{References}

[1] National Association of Colleges and Employers, Job Outlook 2017, http://www.naceweb.org/talent-acquisition/candidate-selection/the-attributes-employers-seek-ona-candidates-resume/

[2] Bell, Robin and Loon, Mark (2015) The Impact of Critical Thinking Disposition on Learning Using Business Simulations. The International Journal of Management Education, 13 (2). pp. $119-127$

[3] Whiteley, T. R., \& Faria, A. J. (1989). A study of the relationship between student final exam performance and simulation game participation. Simulation \& Gaming, 20(1), 44-64.

[4] Doyle, D., \& Brown, F.W. (2000). Using a business simulation to teach applied skills - the benefits and the challenges of using student teams from multiple countries. Journal of European Industrial Training, 24(6), 330-336.

[5] Adobor, H., \& Daneshfar, A. (2006). Management simulations: determining their effectiveness. Journal of Management Development, 25(2), 151e168.

[6] Curry, B., \& Moutinho, L. (1992). Using computer simulations in management education. Management Learning, 23, 155-167. 
[7] Jehn, K. A., \& Mannix, E. A. (2001). The dynamic nature of conflict: a longitudinal study of intragroup conflict and group performance. Academy of Management Journal, 44(2), 238-251.

[8] Morgan, G. (2009). Challenges of online game development: a review. Simulation \& Gaming, 40(5), 688-710.

[9] Anderson, P. H. and Lawton, L. (2009). Business Simulations and Cognitive Learning: Developments, Desires, and Future Directions. Simulation \& Gaming 40(2), 193-216. 